\title{
Artur Janicki*
}

\section{TAXATION OF FREE-OF-CHARGE EMPLOYEE BENEFITS. GLOSS TO THE JUDGEMENT OF THE SUPREME ADMINISTRATIVE COURT OF 29 NOVEMBER 2018, II FSK 799/18}

\begin{abstract}
In this paper, the author presented his critical view of the position which the Supreme Administrative Court expressed in its judgement of 29 November 2018 (II FSK 799/18). ${ }^{1}$ The case in question concerned taxation of free-of-charge employee benefits, which consisted in providing an employee with accommodation in the place of secondiment. The court stated that, as a result of using the accommodation provided, the employee obtained taxable revenue. The author conducted a dogmatic and legal analysis of applicable provisions of the Personal Income Tax Act of 26 July 1991 and referred to views expressed in the doctrine of law and numerous judgements passed by administrative courts. The author paid particular attention to discussing the ruling of the Constitutional Tribunal of 8 July 2014 (K 7/13), in which the conditions under which a free-of-charge employee benefit may be deemed as revenue were described. Furthermore, the author expressed his critical view of the conclusions which arise from the resolution of the Supreme Court of 10 December 2015 (III UZP 14/15) and which the

* Artur Janicki, Ph.D. student, Doctoral School of Social Sciences - Academia Rerum Socialium, Nicolaus Copernicus University in Toruń, e-mail address: janicki@doktorant.umk.pl. ORCID: 0000-0001-8470-933X.

1 Central Database of the Jurisprudence of Administrative Courts (Centralna Baza Orzeczeń Sądów Administracyjnych, hereinafter CBOSA).
\end{abstract}


Supreme Administrative Court passively accepted in its grounds of the judgement in question. Finally, the author demonstrated that in the case in question, the requirement to provide the benefit in the interest of the employee was not met, and thus the benefit should not have been deemed the employee's revenue.

Keywords: personal income tax, employment relationship, free-of-charge employee benefits, employee accommodation, secondment

\section{Introduction}

The judgement of the Supreme Administrative Court (hereinafter: "the SAC") discussed herein concerned the matter of taxation of free-of-charge benefits provided by the employer to its employees by means of ensuring accommodation for the latter in the place of work, which is at a significant distance from their place of residence. In the judgement in question, the SAC definitely departed from the current manner of interpretation of the provisions of the Personal Income Tax Act (hereinafter: "the PITA") ${ }^{2}$ which apply to such employee benefits. ${ }^{3}$ It is an important matter from the perspective of income tax payers and remitters alike, as categorising such benefits as taxable revenues directly affects the amount of the income tax paid by the employees. Furthermore, it gives rise to the obligation on the side of the employer to collect an appropriate income tax prepayment. ${ }^{4}$ This matter is often a subject of disputes between taxpayers and tax authorities, for the applicable regulation leaves large room for interpretation. Moreover, non-salary benefits have recently become very common. ${ }^{5}$ Authorities competent to issue tax law interpretations generally take the view that providing employees with overnight accommodation during work away from their place of residence represents their revenue. The opposite view is held by income tax

2 Personal Income Tax Act of 26 July 1991, Dz.U. (Journal of Laws) of 2019, item 1387, as amended.

3 Judgements of the SAC of 19 September 2014, II FSK 2280/12; of 23 July 2015, II FSK 1689/13; of 15 April 2016, II FSK 635/14; of 17 May 2017, II FSK 1132/15. Available in CBOSA.

4 Breach of this obligation entails the remitter's liability for tax offences under Article 78 of the Penal Fiscal Code Act of 10 September 1999, Dz.U. (Journal of Laws) of 2018, item 1958, as amended.

5 Cf. Marczak, A., Nieodpłatne świadczenia dla pracowników w świetle wyroku Trybunału Konstytucyjnego z dnia 8 lipca 2014 r., K 7/13, "Przegląd Podatkowy" 2014, No. 10, p. 12. 
remitters, most often employers from the construction and assembly industry that second their employees to work abroad. Consequently, they often request individual tax law interpretations.

\section{Background information}

The construction company that requested an individual tax law interpretation seconded its employees abroad. This was not travel for official duties within the meaning of Article $77^{5}$ of the Labour Code, ${ }^{6}$ for the applicable annexes to their employment contracts amended their workplace and remuneration payable. ${ }^{7}$ The company (or its foreign counterparty) would rent, at its own expense, multi-person dwellings of differing standards, which it would subsequently make available to the employees. The company did not keep any detailed records of the utilisation of the accommodation, and it paid the costs of rent regardless of whether the flats were fully occupied or temporarily vacant. The company argued that it had to pay for overnight accommodation in order for its employees to be able to perform their official duties, and therefore the related cost could not be deemed as revenue from the employment relationship in accordance with Article 12, sec. 1 of the PITA.

At first, the Minister of Finance shared the company's view, but the favourable interpretation was changed ex officio in June $2016 .{ }^{8}$ In his reasoning, the Minister pointed out that the value of the benefits concerned represented the employees' revenue, and therefore the company was under obligation to assess and collect the related income tax prepayments. In doing so, the Minister invoked Article 12, sec. 2 in connection with Article 11, sec. 1 and Article 12, sec. 3 in connection with Article 11, sec. 2-2b of the PITA. The company challenged the change to the interpretation before the administrative court, and the court

6 Labour Code Act of 26 June 1974, Dz.U. (Journal of Laws) 2019, item 1040, as amended.

7 Cf. Article 3 of Directive 96/71/EC of 16 December 1996 concerning the posting of workers in the framework of the provision of services, Official Journal of the European Union L $18,21.1 .1997$, pp. 1-6. More on the employer's obligations regarding secondment of employees to work abroad - see: Sokołowska, A., Skibińska, M., Delegowanie pracowników za granicę, Warszawa 2016, pp. 260-261.

8 At that time, the Minister of Finance changed ex officio at least 14 individual interpretations issued in the period concerned. See: Szulc, M., Pokojska, A., Spór o PIT od noclegów dla pracowników wróci do sadów, "Gazeta Prawna" 15.09.2016. Accessed on: 9.11.2019 https://podatki. gazetaprawna.pl/artykuly/976069, pit-od-noclegow-pracownikow-problem-wraca-do-sadu.html. 
supported the position of the company. In its reasoning, the administrative court of first instance explained that the expenses on providing overnight accommodation for the employees were incurred in the employer's interests, for they brought the employer a tangible benefit in the form of appropriate and effective performance of employee responsibilities and, furthermore, served reasonable organisation of work by making it less arduous. The Minister of Finance filed an appeal in cassation against that judgement arguing that it contained an incorrect interpretation of the provisions of the PITA. Taking into consideration the facts of the case, the SAC supported the position of the Minister. The SAC overruled the first instance judgement and dismissed the company's challenge, deeming the substance of the case as sufficiently clarified. ${ }^{9}$

\section{Case analysis}

I. One cannot agree with the SAC judgement. Based on a cursory interpretation of the provisions of law, the court erred in applying Article 12, sec. 1 of the PITA to the facts of the case and stating that the employees received revenues. Although in its reasoning the court cited extensive fragments of judgements passed by the Constitutional Tribunal and the Supreme Court, it failed to conduct an in-depth analysis of those judgements and thus drew unwarranted conclusions. Furthermore, a general conclusion that transpires from the reasoning in question is that revenue is generated each time overnight accommodation is provided freeof-charge to employees, which is in flagrant contradiction with the pro-constitutional interpretation of the provisions of the PITA proposed by the Constitutional Tribunal.

II. Which rules of substantive law should be applied as the basis of the judgement was not a contentious issue in the case in question. In accordance with Article 11 , sec. 1 of the PITA, revenues include cash and pecuniary values received by or made available to the taxpayer in a calendar year, as well as the value of benefits in kind and other free-of-charge benefits. The SAC rightly pointed out that the legal definition of revenues and their statutory catalogue provided in Article 10 of the PITA are general. Therefore, the linguistic interpretation of the

9 The SAC dismissed the challenge pursuant to Article 188 of the Act of 30 August 2002 Proceedings Before Administrative Courts, Dz.U. (Journal of Laws) of 2018, item 1302, as amended. 
provisions concerned should be linked with an internal systemic interpretation. ${ }^{10}$ In the case in question, they should be interpreted in connection with Article 12 of the PITA, where revenues from the employment relationship and similar revenues are described. The legislator recognises all benefits which require a legal bond between the employee and the employer as revenues from the employment relationship. ${ }^{11}$ The catalogue of these revenues includes cash payments, the value of benefits in kind or equivalents thereof, the value of cash benefits paid for the employee, as well as a number of other free-of-charge or reduced-cost benefits. Of the aforementioned revenue catalogue, the term "other free-of-charge benefit," which was not defined by the legislator, raises the most serious doubts. This issue has been the subject of numerous disputes in literature and case law. ${ }^{12}$

The problems regarding the term "other free-of-charge benefit" were principally solved by the Constitutional Tribunal, which interpreted it in the context of employee benefits in its judgement of 8 July 2014 (K 7/13). ${ }^{13}$ The Tribunal stated that the provisions of Article 12, sec. 1 in connection with Article 11, sec. 1 and Article 12, sec. 3 in connection with Article 11, sec. 2-2b of the PITA, interpreted as meaning that "other free-of-charge benefit" is only a material gain of individually defined value received by an employee, are compliant with Article 2 in connection with Article 217 of the Constitution of the Republic of Poland. ${ }^{14}$ The said judgement is therefore an interpretative judgement that recognises at least one variant of interpretation of the rules as compliant with the Constitution. ${ }^{15}$ In its reasoning for the judgement, the Tribunal explained that the scope of a freeof-charge benefit interpreted as revenue includes all economic phenomena and

10 Mastalski, R., Prawo podatkowe, Warszawa 2016, p. 427.

11 In other words, whether benefits are recognised as revenues from the employment relationship depends on whether a specific benefit may be received only by a specific employee. See: Marciniuk, J. (ed.), Podatek dochodowy od osób fizycznych. Komentarz, Warszawa 2017, p. 147.

12 See: Koperkiewicz-Mordel, K., Podatek dochodowy od osób fizycznych, in: Nykiel, W. (ed.), Prawo podatkowe w Polsce. Podręcznik akademicki, Warszawa 2018, p. 191. Cf. judgement of the SAC in Wrocław of 12 May 1999, I SA/Wr 115/98, LEX No. 37247.

13 Dz.U. (Journal of Laws) of 2014, item 947.

14 Constitution of the Republic of Poland of 2 April 1997, Dz.U. (Journal of Laws), No. 78, item 483.

15 More on interpretative judgements of the Constitutional Tribunal - see: Białogłowski, W., Wznowienie postepowania $w$ nastepstwie wydania przez TK wyroku interpretacyjnego, in: Bernatt, M. et al. (eds.), Skutki wyroków Trybunatu Konstytucyjnego w sferze stosowania prawa, Warszawa 2013, pp. 191-198; Woś, T., Wyroki interpretacyjne i zakresowe w orzecznictwie Trybunatu Konstytucyjnego, "Studia Iuridica Lublinensia" 2016, No. 3, Vol. XXV, pp. 985-995. 
legal occurrences that result in free-of-charge (i.e. not related to any costs or other equivalent forms) and financially tangible gain by the person concerned. The Constitutional Tribunal thus accepted the view expressed in resolutions adopted earlier by the SAC. ${ }^{16}$ It also noted that for income to be recognised, it is necessary to have a material profit (gain), which may consist in either increasing the taxpayer's assets or avoiding the expenses (i.e. saving) which the taxpayer would have to incur. According to the Tribunal, only benefits that meet the following three conditions may be recognised as revenues: 1) they have been provided with the employee's consent (the employee has used them on a fully voluntary basis); 2) they have been provided in the employee's interest (not the employer's interest), and the employee has profited from them by increasing his or her assets or avoiding the expenses he or she would have to incur; 3 ) the profit is tangible and allocated to a specific employee (it is not generally available to all entities).

The judgement of the Constitutional Tribunal was welcomed both by the case law and the doctrine of law. ${ }^{17}$ The requirements for a free-of-charge benefit to be recognised as revenue were cited in the case concerned by both the SAC and the court of first instance. However, the conclusions drawn from their analysis were completely different. Neither the company in the case nor the Minister of Finance challenged the fact that the requirements concerning the employee's consent and individualisation of the benefit had been met. ${ }^{18}$ The doubts concerned only the assessment in whose interest the overnight accommodation at the place of work was provided. In the opinion of the SAC, the assessment arose directly from the reasoning for the judgement by the Constitutional Tribunal, which stated that the situation was completely clear when one's contract of employment specified benefits which the employer would provide to the employee, e.g. company

16 Resolutions of the SAC of 24 May 2010, II FPS 1/10, CBOSA; of 24 October 2011, II FPS $7 / 10$, CBOSA. The fact that the Constitutional Tribunal invoked the said resolutions has attracted the criticism of some commentators, cf. Mariański, A., Nowak-Piechota, A., Glosa cześciowo aprobujaca do wyroku Trybunału Konstytucyjnego z dnia 8 lipca 2014 r., K 7/13, "Przegląd Podatkowy" 2014, No. 11, p. 46; Olesiak, J., Pajor, Ł., Glosa do wyroku Trybunatu Konstytucyjnego z dnia 8 lipca 2014 r., K 7/13, "Przegląd Orzecznictwa Podatkowego" 2015, No. 1, p. 13.

17 Cf. Marczak, A., op. cit., pp. 13-20; Mariański, A., Nowak-Piechota, A., op. cit., pp. 43-46; Olesiak, J., Pajor, Ł., op. cit., pp. 10-13.

18 It does not mean, however, that the requirements will be met in every case with similar facts. If there is objectively no alternative choice of accommodation at a given place of work, then it is doubtful that the "voluntary basis" requirement can be met. Furthermore, the benefit may occur impossible to be individualised when the employees are provided with a single large "rotation" flat in which they stay occasionally for a few days at a stretch at most. Cf. judgement of the VAC in Warsaw of 17 October 2017, III SA/Wa 2555/16, CBOSA. 
flat, monthly transport ticket, health insurance package, transport to work (point 3.4.3 of the reasoning for the judgement by the Constitutional Tribunal). The SAC recognised the judgement by the Constitutional Tribunal as unambiguous in this respect and confined itself to a laconic statement that such a situation could be seen in the case in question.

However, the matter is not as obvious as the SAC said it was. Indeed, the court failed to thoroughly consider the issue of which of the parties - the employee or the employer - gains benefits. According to the Tribunal, a gain appears when an employee has received a benefit at his or her own disposal and can freely manage and use it to satisfy his or her own needs (point 3.4.2. of the reasoning to the judgement by the Constitutional Tribunal). In light of the facts of the case, however, the employee's rights to the dwelling made available to him or her were materially restricted. The rented flats remained at the disposal of the employer, who not only assigned specific flats to individual employees, but also paid the rent regardless of how long they actually used the accommodation. When an employer seconds employees to work abroad, giving them flats at their free disposal is certainly not in its interest. Indeed, the employer has no interest in allowing its employee to live there with his or her family, let any third parties into the flat, leave his or her belongings inside during his or her permanent absence or sub-rent the accommodation to third parties. ${ }^{19}$ The freedom of disposal in this sense is what makes "a company flat," as referred to in the judgement by the Constitutional Tribunal, different from employee accommodation, which in fact is just a night shelter and a place to rest for the employee.

Furthermore, the position held by the SAC unjustifiably ignores the view taken by the Constitutional Tribunal as regards the gains obtained by an employee. According to the Tribunal, there is hardly any gain for the employee if he or she cannot take the benefit "outside the employment relationship" (point 3.3.2. of the reasoning for the Constitutional Tribunal). This is exactly so in the case concerned, for the overnight accommodation is strictly and solely linked with the employment relationship. One should note that the employees use the flat in their breaks from work. Contrary to what the SAC stated, such overnight accommodation is a nuisance rather than a benefit. ${ }^{20}$ The employees are guided

19 In principle, the tenant cannot hand over the rented property for free-of-charge use or sublet it, without the landlord's consent - in accordance with Article $668^{2}$ of the Civil Code Act of 23 April 1964, Dz.U. (Journal of Laws) of 2019, item 1145, as amended.

20 Cf. judgement of the VAC in Warsaw of 10 March 2016, III SA/Wa 3984/14, CBOSA. 
by their intention to earn an income, not to satisfy their private needs. Nobody would use accommodation provided by the employer if they were not seconded to work away from their place of residence. ${ }^{21}$

The view invoked by the SAC, according to which, in the absence of the benefit, the employee would have to pay for his or her housing needs himself or herself, should also be found as illogical and clearly removed from reality. Group accommodation is perceived by employees as one of the key requirements for providing work, a condition on which they base their consent to be seconded, and is not perceived as a component of their remuneration. Firstly, finding and renting a flat by the employee himself or herself is impossible or at least difficult due to a higher price (compared to group accommodation) and the need to finalise the related formalities, which requires foreign language competency. Secondly, the average construction worker cannot afford to pay a high deposit for renting a flat abroad, which in Germany may amount even up to three monthly rents. ${ }^{22}$

Finally, it should be emphasised that the employer, by offering group overnight accommodation, pursues its own interest, i.e. the intention to ensure the safety of its employees and effective utilisation of their working time. Regardless of whether the requirement to provide overnight accommodation is rooted in law or is just a fact, it is not a right, but rather an obligation on the side of the employee to use the overnight accommodation offered by the employer. Indeed, in the absence of such benefit, the employee would himself or herself have to find somewhere to stay. However, the case in question is not about any place of overnight stay, but about the one specific place selected and preferred by the employer. The fact that the employee stays there serves the employer's economic interests. This is connected with a thesis present in the case law, according to which overnight accommodation is a kind of "work tool". Although the thesis does not seem to be optimal, one has to admit that its supporters are correct. ${ }^{23}$

The above arguments clearly show that one cannot draw hasty conclusions from the verdict passed by the Constitutional Tribunal as the SAC did in its judgeCBOSA.

21 Similarly - the VAC in Warsaw in its judgement of 7 February 2018, III SA/Wa 594/17,

22 See $\S 551$ Para. 1 Bürgerliches Gesetzbuch (German Civil Code). Accessed on: 9.11.2019. https://www.gesetze-im-internet.de/bgb/.

23 Cf. judgements of the SAC of 2 October 2014, II FSK 2387/12; of 17 May 2017, II FSK 1132/15; judgement of the VAC in Warsaw of 18 October 2017, III SA/Wa 3045/16; judgement of the VAC in Gliwice of 25 October 2017, I SA/Gl 602/17. Available in CBOSA. 
ment discussed in this paper. A comprehensive and thorough analysis of premises pointed out by the Tribunal, already at this stage of deliberations, leads one to conclude that the employee does not obtain any revenue as a result of using accommodation made available by the employer. However, one must not content oneself with this conclusion, for further in its reasoning, the SAC refers to other issues which undoubtedly had a certain impact on the final decision in the case in question.

III. The court could have certain doubts with regard to questioning whether the employer's obligations included the requirement to provide overnight accommodation to its seconded employees. ${ }^{24}$ In order to dispel these doubts in interpretation, the SAC drew attention to the content of the resolution of the Supreme Court of 10 December 2015 (III UZP 14/15). ${ }^{25}$ Although the resolution concerned mobile, and not seconded, employees, there are no obstacles that would prevent consideration of the view of the Supreme Court in the context discussed in this paper. ${ }^{26}$

The thesis of the said resolution of the Supreme Court is that revenues - in accordance with the provisions of the Social Insurance Scheme $\mathrm{Act}^{27}$ - include the value of employee accommodation benefits provided by the employer, which thus constitute the basis for calculating social insurance contributions. ${ }^{28}$ In its reasoning, the court clarified that a flat made available to an employee cannot be regarded as "a work tool," for it serves the satisfaction of off-work living needs (i.e. social needs). According to the Supreme Court, provisions of law do not oblige an employer to provide its employees with "a place of residence" in which

24 The Labour Code stipulates the obligation to organise work in a manner that makes it less onerous (Article 94, point 2a of the Labour Code) and provides for full utilisation of the work time (Article 94, point 2 of the Labour Code). Commentators also call the latter obligation a reasonable work time organisation. See: Nałęcz, M., Obowiazki pracodawcy, in: Muszalski, W. (ed.), Kodeks pracy. Komentarz, Warszawa 2017, pp. 221-222; Świątkowski, A., Kodeks pracy. Komentarz, Warszawa 2018, p. 593.

25 Jurisprudence of the Supreme Court: Labour Law, Social Security and Public Affairs Chamber (Orzecznictwo Sądu Najwyższego: Izba Pracy, Ubezpieczeń Społecznych i Spraw Publicznych - OSNP), 2016/6/74.

26 It should be clarified that mobile employees include, for instance, sales representatives, drivers, sometimes also construction workers, whose work requires constant mobility and whose place of work is defined as a specific geographical area. See: Sokołowska, A., Skibińska, M., op. cit., pp. 22-25.

27 Social Insurance Scheme Act of 13 October 1998, Dz.U. (Journal of Laws) of 2019, item 300 , as amended.

28 "Revenue" within the meaning of the Social Insurance Scheme Act can be considered equivalent to "revenue" within the meaning of the PITA, and therefore the deliberations of the Supreme Court should be considered as relevant to the case in question. 
they could satisfy their living needs. ${ }^{29}$ If it is required to provide accommodation to an employee to enable him or her to work, then it is a factual - not legal requirement which the employee must take into account when commencing work far away from his or her place of residence. The onerous nature of working away from one's life centre may only affect the amount of one's remuneration for work. Furthermore, the Supreme Court referred to Article Article 21, sec. 1, point 19 1, point 19 of the PITA, which in its view defines certain "other free-of-charge benefits," including the value of employee accommodation benefits provided by the employer, which is tax-free up to the amount of PLN 500 per month. In the view of the Supreme Court, that value is an employee's revenue, but up to the specific amount (PLN 500), it is considered by the legislator as a revenue earning cost.

Although the position held by the Supreme Court was by no means binding for the SAC, the latter fully accepted the views presented in the resolution. Thus, it moved away from the view established in the case law of administrative courts, according to which provision of overnight accommodation to employees falls within the scope of the reasonable work organisation obligation, provided that the use of such benefit is required for the employees to be able to meet their work responsibilities. ${ }^{30}$

However, the interpretation of the provisions of the Civil Code should not be given as much significance as the Supreme Court did and which the SAC passively accepted. Indeed, it is of crucial importance to resolve the two fundamental issues discussed in the judgement by the Constitutional Tribunal namely, in whose interest it is to provide overnight accommodation and whether the employer does in fact "act in lieu of" its employee by paying the cost of the employee's accommodation in the latter's place of secondment. One should assume that the SAC deemed itself bound by the Constitutional Tribunal's judgement in this respect. ${ }^{31}$ Therefore, the view held by the SAC should not incorporate

29 The Supreme Court, probably by mistake, used the term "place of residence" instead of "accommodation." It would be completely absurd to admit that the court referred here to the term defined in Article 25 of the Civil Code. Indeed, a mobile employee (and a seconded employee, for that matter) never intends to reside permanently in a locality in which he or she provides work. Cf. Strugała, R., Miejsce zamieszkania, in: Gniewek, E. (ed.), Kodeks cywilny. Komentarz, Warszawa 2017, pp. 65-66.

30 Judgements of the SAC of 19 September 2014, II FSK 2280/12; of 2 October 2014, II FSK 2387/12; of 9 August 2016, II FSK 1970/14; judgement of the VAC in Warsaw of 28 September 2017, III SA/Wa 3309/16. Available in CBOSA.

31 In principle, administrative courts accept that verdicts passed by the Constitutional Tribunal are universally applicable. See: Białogłowski, W., op. cit., p. 202. 
those statements made by the Supreme Court which are in flagrant contradiction with the judgement of the Constitutional Tribunal. The Supreme Court's thesis referring to Article Article 21, sec. 1, point 19 1, point 19 of the PITA should be considered as such. Contrary to what the Supreme Court stated, the purposive interpretation does not lead to a conclusion that the inclusion of the employee accommodation benefit in the tax exemption catalogue would mean that revenue is always generated in such a situation. Referring to non-linguistic interpretation was unfounded in this case, for the findings of the linguistic interpretation leave no doubt. ${ }^{32}$ Article 21, sec. 1 of the PITA states that "income tax-free are...," not that "the following revenues shall be exempt from the income tax." The Constitutional Tribunal clearly contradicted such purposive interpretation by stating that tax exemptions of specific employee benefits "rather show that the values subject to exemption are not considered by the legislator as an employee's income" (point 3.3.2. of the reasoning for the judgement of the Constitutional Tribunal).

\section{Conclusions}

The arguments presented herein speak in favour of the conclusion that the SAC's ruling is incorrect. In the context of the case analysed, the expense on accommodating a seconded employee was incurred in the interest of the employer. Therefore, one of the premises pointed out by the Constitutional Tribunal was not met. The position held by the SAC cannot be considered objective, as it partly adopts the approach of the Constitutional Tribunal, while disregarding the arguments speaking in favour of the taxpayer. It seems that by adopting the views expressed in the Supreme Court's resolution, the SAC fell into a routine manner of thinking by accepting that the taxation of free-of-charge employee benefits aims at completeness, i.e. at taxing all socio-economic phenomena. ${ }^{33} \mathrm{It}$ is hard to resist the impression that the SAC made its deliberations somehow in isolation from the facts of this specific tax case and referred generally to all cases of employee accommodation provided by employers. Such generalisation certainly cannot be justified in cases where the dispute concerns interpretation of an imprecisely defined term. Whether the requirements for recognising an employee benefit as revenue that arise from the Constitutional Tribunal's judgement are met

32 As regards admissibility of the purposive interpretation - see: Brzeziński, B., Podstawy wyktadni prawa podatkowego, Gdańsk 2008, p. 92.

33 Ibidem, p. 64. 
should be analysed in concreto, even in a seemingly obvious case where a flat is given to an employee at his or her free disposal.

For the abovementioned reasons, the change in the case law initiated by the judgement commented herein is difficult to accept. It can be seen in recent judgements by administrative courts that the interpretation of the law, which is unfavourable to taxpayers, has been expanded to include cases of accommodation of seconded and mobile employees, ${ }^{34}$ as well as contractors. ${ }^{35}$ However, the view expressed in the judgement discussed herein is still disputed. ${ }^{36}$ Finally, one can hope that we are not in danger of a return to "the madness of taxing free-of-charge benefits," as it was colloquially described by Professor Bogumił Brzeziński a decade ago. ${ }^{37}$

34 Judgement of the SAC of 23 July 2019, II FSK 2721/17; judgement of the VAC in Gorzów Wielkopolski of 8 May 2019, I SA/Go 163/19; judgement of the VAC in Gliwice of 8 July 2019, I SA/G1 248/19. Available in CBOSA.

35 Judgements of the SAC of 13 August 2019: II FSK 2724/17 and II FSK 2904/17; judgement of the VAC in Gliwice of 16 January 2019, I SA/G1 871/18; judgement of the VAC in Rzeszów of 9 April 2019, I SA/Rz 136/19. Available in CBOSA. CBOSA.

36 Judgement of the VAC in Warsaw of 14 December 2018, III SA/Wa 304/18 (non-final),

37 Brzeziński, B., Szaleństwo opodatkowania nieodpłatnych świadczeń, "Kwartalnik Prawa Podatkowego 2010", No. 3-4, pp. 115-117. 


\section{Literature}

Białogłowski, W., Wznowienie postępowania $w$ następstwie wydania przez TK wyroku interpretacyjnego, in: Bernatt, M., Królikowski, J., Ziółkowski, M. (eds.), Skutki wyroków Trybunatu Konstytucyjnego w sferze stosowania prawa, Warszawa 2013.

Brzeziński, B., Podstawy wykładni prawa podatkowego, Gdańsk 2008.

Brzeziński, B., Szaleństwo opodatkowania nieodpłatnych świadczeń, "Kwartalnik Prawa Podatkowego" 2010, No. 3-4.

Koperkiewicz-Mordel, K., Podatek dochodowy od osób fizycznych, in: Nykiel, W. (ed.), Prawo podatkowe w Polsce. Podręcznik akademicki, Warszawa 2018.

Marciniuk, J. (ed.), Podatek dochodowy od osób fizycznych. Komentarz, Warszawa 2017.

Marczak, A., Nieodpłatne świadczenia dla pracowników w świetle wyroku Trybunału Konstytucyjnego z dnia 8 lipca 2014 r., K 7/13, "Przegląd Podatkowy" 2014, No. 10.

Mariański, A., Nowak-Piechota, A., Glosa częściowo aprobująca do wyroku Trybunatu Konstytucyjnego z dnia 8 lipca 2014 r., K 7/13, "Przegląd Podatkowy" 2014, No. 11.

Mastalski, R., Prawo podatkowe, Warszawa 2016.

Nałęcz, M., Obowiązki pracodawcy, in: Muszalski, W. (ed.), Kodeks pracy. Komentarz, Warszawa 2017.

Olesiak, J., Pajor, Ł., Glosa do wyroku Trybunału Konstytucyjnego z dnia 8 lipca 2014 r., $K$ 7/13, "Przegląd Orzecznictwa Podatkowego" 2015, No. 1.

Sokołowska, A., Skibińska, M., Delegowanie pracowników za granicę, Warszawa 2016. Strugała, R., Miejsce zamieszkania, in: Gniewek, E. (ed.), Kodeks cywilny. Komentarz, Warszawa 2017.

Świątkowski, A., Kodeks pracy. Komentarz, Warszawa 2018.

Szulc, M., Pokojska, A., Spór o PIT od noclegów dla pracowników wróci do sąów, "Gazeta Prawna”, 15.09.2016. Accessed on: 9.11.2019. https://podatki.gazetaprawna. pl/artykuly/976069,pit-od-noclegow-pracownikow-problem-wraca-do-sadu.html.

Woś, T., Wyroki interpretacyjne i zakresowe w orzecznictwie Trybunału Konstytucyjnego, "Studia Iuridica Lublinensia" 2016, No. 3, vol. XXV.

\section{Legislation}

Act of 30 August 2002 on Proceedings Before Administrative Courts, Dz.U. (Journal of Laws) of 2018, item 1302, as amended.

Bürgerliches Gesetzbuch (German Civil Code). Accessed on: 09.11.2019. https://www. gesetze-im-internet.de/bgb/. 
Civil Code Act of 23 April 1964, Dz.U. (Journal of Laws) of 2019, item 1145, as amended.

Constitution of the Republic of Poland of 2 April 1997, Dz.U. (Journal of Laws), No. 78, item 483.

Directive 96/71/EC of 16 December 1996 concerning the posting of workers in the framework of the provision of services, Official Journal of the European Union L 18, 21.1.1997, pp. 1-6.

Labour Code Act of 26 June 1974, Dz.U. (Journal of Laws) of 2019, item 1040, as amended.

Personal Income Tax Act of 26 July 1991, Dz.U. (Journal of Laws) of 2019, item 1387, as amended.

Penal Fiscal Code Act of 10 September 1999, Dz.U. (Journal of Laws) of 2018, item 1958, as amended.

Social Insurance Scheme Act of 13 October 1998, Dz.U. (Journal of Laws) of 2019, item 300 , as amended.

\section{Judicial decisions}

Judgement of the Constitutional Tribunal of 8 July 2014, K 7/13, Dz.U. (Journal of Laws) of 2014, item 947.

Judgement of the Supreme Administrative Court in Wrocław of 12 May 1999, I SA/Wr 115/98, LEX No. 37247.

Judgement of the Supreme Administrative Court of 19 September 2014, II FSK 2280/12, CBOSA.

Judgement of the Supreme Administrative Court of 2 October 2014, II FSK 2387/12, CBOSA.

Judgement of the Supreme Administrative Court of 23 July 2015, II FSK 1689/13, CBOSA. Judgement of the Supreme Administrative Court of 15 April 2016, II FSK 635/14, CBOSA. Judgement of the Supreme Administrative Court of 9 August 2016, II FSK 1970/14, CBOSA.

Judgement of the Supreme Administrative Court of 17 May 2017, II FSK 1132/15, CBOSA. Judgement of the Supreme Administrative Court of 23 July 2019, II FSK 2721/17, CBOSA. Judgement of the Supreme Administrative Court of 13 August 2019, II FSK 2724/17, CBOSA.

Judgement of the Supreme Administrative Court of 13 August 2019, II FSK 2904/17, CBOSA. 
Judgement of the Voivodeship Administrative Court in Warsaw of 10 March 2016, III SA/Wa 3984/14, CBOSA.

Judgement of the Voivodeship Administrative Court in Warsaw of 28 September 2017, III SA/Wa 3309/16, CBOSA.

Judgement of the Voivodeship Administrative Court in Warsaw of 17 October 2017, III SA/Wa 2555/16, CBOSA.

Judgement of the Voivodeship Administrative Court in Warsaw of 18 October 2017, III SA/Wa 3045/16, CBOSA.

Judgement of the Voivodeship Administrative Court in Gliwice of 25 October 2017, I SA/Gl 602/17, CBOSA.

Judgement of the Voivodeship Administrative Court in Warsaw of 7 February 2018, III SA/Wa 594/17, CBOSA.

Judgement of the Voivodeship Administrative Court in Warsaw of 14 December 2018, III SA/Wa 304/18, CBOSA.

Judgement of the Voivodeship Administrative Court in Gliwice of 16 January 2019, I SA/ G1 871/18, CBOSA.

Judgement of the Voivodeship Administrative Court in Rzeszów of 9 April 2019, I SA/ Rz 136/19, CBOSA.

Judgement of the Voivodeship Administrative Court in Gorzów Wielkopolski of 8 May 2019, I SA/Go 163/19, CBOSA.

Judgement of the Voivodeship Administrative Court in Gliwice of 8 July 2019, I SA/G1 248/19, CBOSA.

Resolution of the Supreme Court of 10 December 2015, III UZP 14/15, OSNP 2016/6/74.

Resolution of the Supreme Administrative Court of 24 May 2010, II FPS 1/10, CBOSA.

Resolution of the Supreme Administrative Court of 24 October 2011, II FPS 7/10, CBOSA. 